\title{
Diagnostic challenges in compound heterozygous Hb Lepore/ $\beta$ thalassaemia presenting as thalassaemia major
}

*R Warushahennadi ${ }^{1}$, K Jayasinghe ${ }^{2}, \mathbf{R}$ Ananda $^{3}$

Sri Lanka Journal of Child Health, 2022: 51(1): 146-148

DOI: http://dx.doi.org/10.4038/sljch.v51i1.10024

(Key words: Haemoglobinopathy, Lepore)

\begin{abstract}
Introduction
Haemoglobin $(\mathrm{Hb})$ Lepore $[\alpha 2(\delta \beta)$ 2] is a structurally abnormal $\mathrm{Hb}$, resulting from a fusion between a $\delta$ and a $\beta$ globin gene during meiosis. The hybrid gene is formed by the fusion of 5 ' end of the $\delta$ globin gene and the 3 ' end of the $\beta$ globin gene. Three Hb Lepore variants have been identified, each with a different crossover breakpoint: $\mathrm{Hb}$ Lepore Washington Boston ( $\delta 87 / \beta 116)$, $\mathrm{Hb}$ Lepore Hollandia $(\delta 22 / \beta 50)$ and $\mathrm{Hb}$ Lepore Baltimore $(\delta 50 / \beta 86)$. Hb Lepore Washington Boston is the most common variant. In all three variants, synthesis of these $\delta \beta$ hybrid chains is substantially less than that of the normal $\beta$ chain ${ }^{1,2,3,4}$. Hb Lepore occurs with a low frequency in a variety of ethnic groups, mainly in Mediterranean countries. It has rarely been detected in Southeast Asian countries ${ }^{1}$. Laboratory diagnosis of the carrier state of $\mathrm{Hb}$ Lepore is rarely a problem since HPLC is able to give a presumptive diagnosis. On HPLC, Hb Lepore co-elutes with $\mathrm{HbA} 2$ giving a combined level of less than $15 \%$. However, in compound heterozygous states, the diagnosis may not be apparent as the variant $\mathrm{Hb}$ is not easily detectable due to a much lower level ${ }^{1,3,4}$. We report an infant from a Sri Lankan family with Tamil ethnicity with compound heterozygote $\mathrm{Hb}$ Lepore and $\beta$-thalassaemia, and a clinical picture of transfusion dependent thalassaemia (TDT), highlighting the challenges in diagnosis.
\end{abstract}

${ }^{1}$ Consultant Haematologist, Medical Research Institute, Colombo 8, Sri Lanka, ${ }^{2}$ Consultant Haematologist, Teaching Hospital, Batticaloa, Sri Lanka, ${ }^{3}$ Medical officer, Medical Research Institute, Colombo 8, Sri Lanka

*Correspondence: rgodakandage@yahoo.com

iD)

https//orcid.org/ 0000-0002-2947-0394

(Received on 13 January 2021: Accepted after revision on 19 February 2021)

The authors declare that there are no conflicts of interest

Personal funding was used for the project.

Open Access Article published under the Creative

Commons Attribution CC-BY (c) (i) License

\section{Case report}

A five month old baby girl, the first baby of nonconsanguineous parents, presented with severe pallor, hepatomegaly and splenomegaly. Her full blood count (FBC) revealed a $\mathrm{Hb}$ of $2.9 \mathrm{~g} / \mathrm{dl}$, mean corpuscular volume (MCV) of $69.3 \mathrm{fl}$, mean corpuscular haemoglobin $(\mathrm{MCH})$ of $22.3 \mathrm{pg}$ and a mean corpuscular haemoglobin concentration (MCHC) of $32.2 \mathrm{~g} / \mathrm{dl}$. Her reticulocyte count was elevated (18.8\%). Serum ferritin was $171 \mathrm{ng} / \mathrm{ml}$. Blood picture showed evidence of chronic haemolysis (Figure 1). Based on the clinical picture and preliminary haematology, the baby was suspected of having TDT. The baby was transfused with $\mathrm{ABO}$ and Rh compatible leuco-reduced blood to correct anaemia after sending samples for extended red cell phenotyping and high performance liquid chromatography (HPLC).

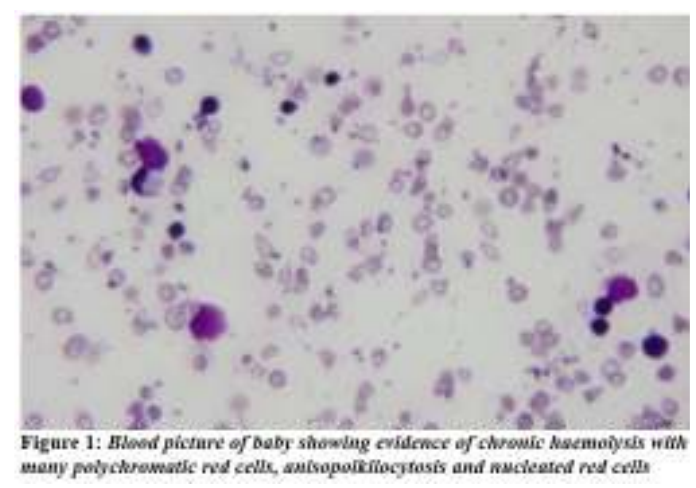

HPLC of the baby using a Bio-Rad Variant $\mathrm{Hb}$ Testing system with ' $\beta$-thalassaemia short programme' revealed raised $\mathrm{Hb} \mathrm{F}(87.9 \%)$ and $\mathrm{Hb}$ A2 (9.9\%). The retention time of $\mathrm{Hb}$ A2 was at 3.47 with a small shoulder at $\mathrm{Hb} \mathrm{A} 2$ window. As there was a small shoulder at $\mathrm{Hb} \mathrm{A} 2$ window, the presence of a variant $\mathrm{Hb}$ was suspected; capillary electrophoresis (Sebia) was performed, which showed raised $\mathrm{Hb} \mathrm{F}(94.3 \%)$ and the presence of a variant $\mathrm{Hb}$ at zone $6(4.5 \%)$ and $\mathrm{Hb} \mathrm{A} 2$ of $1.2 \%$ (Figure 2).

Parental screening was arranged later which showed the father was a carrier for $\mathrm{Hb}$ Lepore and the mother was a carrier for $\beta$ thalassaemia. Both were asymptomatic and not screened for thalassaemia before (Table 1 and Figure 3). 

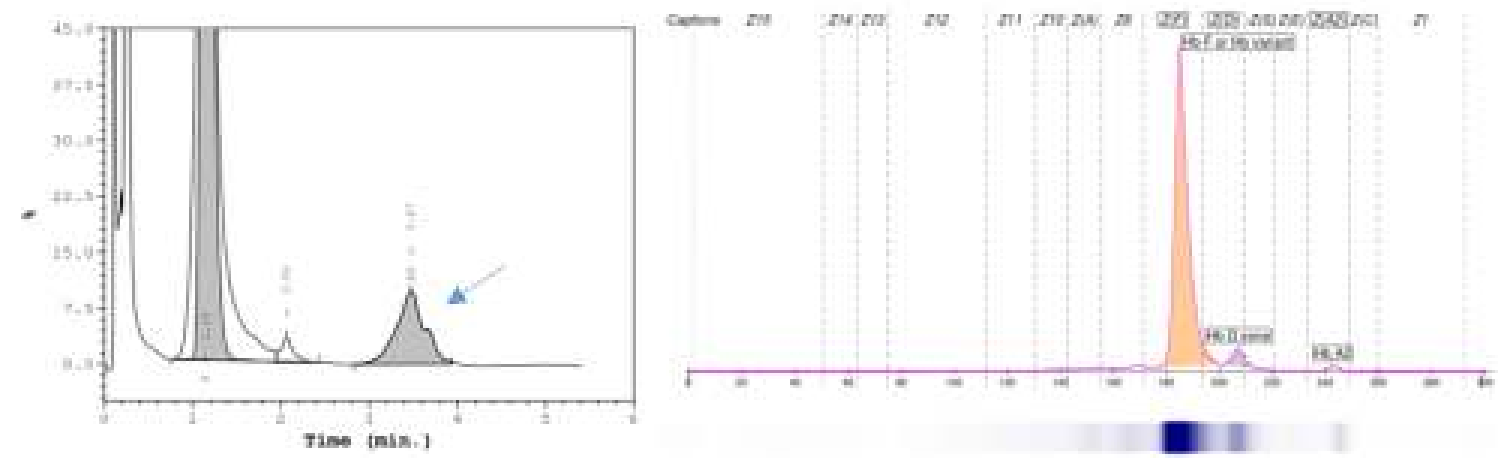

Figure 2: HPLC and CE tracings of the baby

HPLC: high perfomance liguid chromatogrophy, CE: capillary electrophoresis

Table 1: FBC / HPLC /CE parameters of the proband, father and mother

\begin{tabular}{|l|c|c|c|}
\hline \multicolumn{1}{|c|}{ FBC / HPLC / CE parameters } & Proband & Father & Mother \\
\hline Red blood cell count & $1.30 \times 10^{6} / \mu \mathrm{L}$ & $6.01 \times 10^{6} / \mu \mathrm{L}$ & $5.27 \times 10^{6} / \mu \mathrm{L}$ \\
\hline Haemoglobin level & $2.9 \mathrm{~g} / \mathrm{dL}$ & $13.4 \mathrm{~g} / \mathrm{dL}$ & $10.1 \mathrm{~g} / \mathrm{dL}$ \\
\hline Mean corpuscular volume & $69.3 \mathrm{fl}$ & $83.0 \mathrm{fl}$ & $58.0 \mathrm{fl}$ \\
\hline Mean corpuscular haemoglobin & $22.3 \mathrm{pg}$ & $22.3 \mathrm{pg}$ & $19.1 \mathrm{pg}$ \\
\hline Mean corpuscular haemoglobin concentration & $32.2 \mathrm{~g} / \mathrm{dl}$ & $26.8 \mathrm{~g} / \mathrm{dl}$ & $33.0 \mathrm{~g} / \mathrm{dl}$ \\
\hline Red cell distribution width & $39.1 \%$ & $15.1 \%$ & $15.4 \%$ \\
\hline Haemoglobin A (HPLC) & $1.4 \%$ & $74.9 \%$ & $84.0 \%$ \\
\hline Haemoglobin A2 (HPLC) & $9.9 \%$ & $13.0 \%$ & $5.5 \%$ \\
\hline Haemoglobin F (HPLC) & $87.9 \%$ & $1.4 \%$ & $1.1 \%$ \\
\hline Haemoglobin A (CE) & $94.3 \%$ & $80.4 \%$ & $\mathrm{CE}$ not done \\
\hline Haemoglobin A2 (CE) & $1.2 \%$ & $2.7 \%$ & - \\
\hline Haemoglobin F (CE) & $94.3 \%$ & $13.1 \%$ & \\
\hline Abnormal Haemoglobin (CE) & $4.5 \%$ & & \\
\hline
\end{tabular}

FBC: full blood count, HPLC: high performance liquid chromatography, CE: capillary electrophoresis

Anstroch atementes
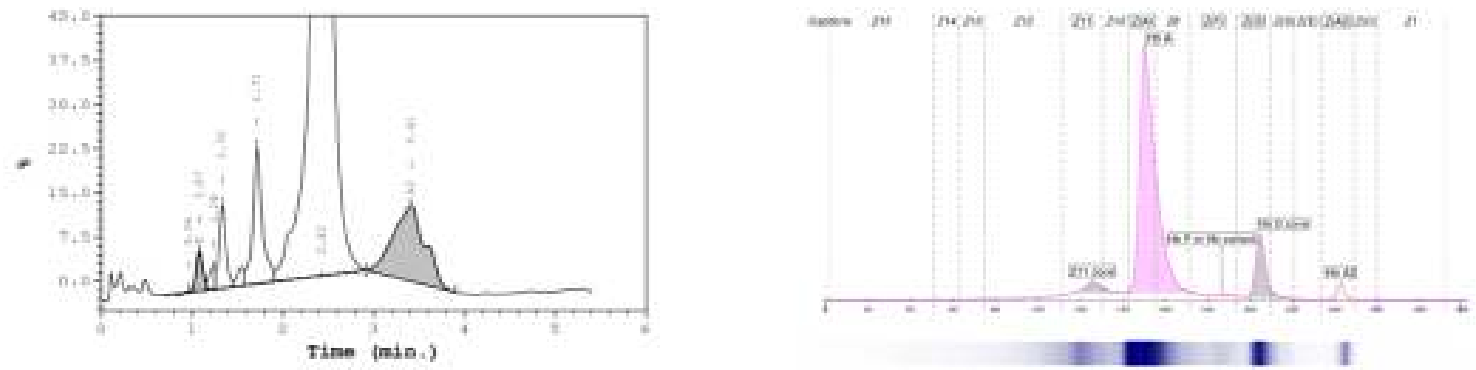

Figure 3: Father's HPLC and CE tracings

HPLC: high performance hiquid chromatography, CE: capillary electrophoresis 
The parents were counselled. The possibility of having a thalassaemic baby in a future pregnancy was explained. Long term management plan of the baby was explained highlighting the importance of adhering to transfusion protocol and the future need for iron chelation.

\section{Discussion}

In compound heterozygous states of $\mathrm{Hb}$ Lepore with other thalassaemias or haemoglobinopathies including $\beta$-thalassaemia, $\mathrm{Hb} \mathrm{S}$ and $\mathrm{Hb} \mathrm{E}$, the patient's phenotypes can be a variation from NonTransfusion Dependent Thalassaemia (NTDT) to Transfusion Dependent Thalassaemia (TDT). The haematological findings in these patients, including peripheral blood film features, are indistinguishable from severe forms of $\beta$-thalassaemia ${ }^{1,4}$. In the compound heterozygous state of $\mathrm{Hb}$ Lepore/ $\beta$ thalassaemia, HPLC shows increased $\mathrm{Hb} F$ and $\mathrm{Hb}$ $\mathrm{A} 2$ with or without $\mathrm{Hb} \mathrm{A}{ }^{1}$. CE shows $\mathrm{Hb}$ F, $\mathrm{Hb}$ A2 and a variant $\mathrm{Hb}$ band at zone 6 (Hb Lepore) with or without $\mathrm{Hb} \mathrm{A}$.

In our patient, clinical presentation, blood counts and blood picture were compatible with $\beta$ thalassaemia major. HPLC showed prominent $\mathrm{Hb} F$, elevated $\mathrm{Hb} \mathrm{A} 2$ and reduced $\mathrm{Hb} \mathrm{A}$, which was similar to $\beta$-thalassaemia major (homozygous $\beta$ thalassaemia). (Hb A2 percentage may be normal, elevated or occasionally reduced in $\beta$ thalassaemia major $^{1}$ ). In the proband's HPLC, the small shoulder in $\mathrm{Hb} \mathrm{A} 2$ band was a lead to repeat analysis on $\mathrm{CE}$ which was able to detect the small $\mathrm{Hb}$ Lepore $(4.5 \%)$.

For a presumptive identification of abnormal haemoglobin, at least two methods should be used ${ }^{1}$; these methods include $\mathrm{Hb}$ electrophoresis at alkaline and acid $\mathrm{pH}$ using cellulose acetate membrane, isoelectric focusing (IEF), HPLC, and CE. In Sri Lanka, most of the thalassaemia screening centres have only one presumptive $\mathrm{Hb}$ identification method; either HPLC or CE. When only one identification method is used, diagnosis of compound heterozygosity may be challenging, as in our case.

Parental screening is always helpful in confirming compound heterozygous haemoglobinopathies. In our case, parental screening confirmed the diagnosis of compound heterozygous $\mathrm{Hb}$ Lepore/ $\beta$ thalassaemia of the baby. Molecular genetic studies are also important in accurate characterization of complex haemoglobinopathies. In Sri Lanka, molecular genetic studies for haemoglobinopathy diagnosis are not freely available.
Management of compound heterozygous $\mathrm{Hb}$ Lepore/ $\beta$-thalassaemia depends on the clinical phenotype. Correct diagnosis of the haemoglobinopathy is essential for clinical management and genetic counselling. Our case was managed as TDT as the baby presented in early age with severe anaemia requiring blood transfusion

Our case highlights the importance of logical approach in haemoglobinopathy diagnosis and the importance of analysis by two methods if a variant $\mathrm{Hb}$ is suspected. Parental screening is always helpful in diagnosing difficult cases.

\section{References}

1. Bain BJ. Haemoglobinopathy diagnosis. 2nd ed. Blackwell publishing, 2011.

2. Sreedharanunni S, Chhabra S, Hira JK, Bansal D, Sharma P, Das R. $\beta$-Thalassemia intermedia caused by compound heterozygosity for $\mathrm{Hb}$ Lepore-Hollandia and $\beta$-Thalassemia is rare in the Indian population; Hemoglobin: 2015: 39(5): 3625 .

3. Hafiza A, Suziana MN, Madzlifah A, Raja Zahratul Azma RS , Azlin I, Noor HH, et al. $\mathrm{Hb}$ Lepore $/ \beta 0$-thalassaemia with $\alpha+-$ thalassaemia interactions, a potential diagnostic pitfall. Malaysian Journal of Pathology 2015: 37(3): 287-92.

4. Schiliro G, Musumeci S, Pizzarelli G, Fischer A, Romero MA, Russo G. Haemoglobin Lepore Boston-Washington in Sicily. Clinical, haematological and biosynthetic studies. Journal of Medical Genetics 1980; 17(3): 179-82.

https://doi.org/10.1136/jmg.17.3.179

5. Azar Keyvan A, Najmabadi H, Esteghamat FAS, Imanian $\mathrm{H}$, Ebrahim Khani S. A case of haemoglobin Lepore combined with beta thalassaemia. Scientific Journal of Iranian Blood Transfusion Organisation 2007; 4(3): 2316. 